\title{
Pengaruh Luasan Lahan Usaha Pendederan Ikan Bawal (Colossoma macropumum) Terhadap Pendapatan Yang Disetarakan Dengan Upah Minimum Regional (UMR) Di Bogor
}

\author{
Oleh: \\ Paidi, Azam B. Zaidy \\ Dosen Jurusan Penyuluhan Perikanan Sekolah Tinggi Perikanan
}

\begin{abstract}
ABSTRAK
Permintaan ikan bawal konsumsi menunjukan kecenderungan meningkat. Hal ini membawa dampak yang baik pembudidaya pembesaran. Disisi lain sekuen pembesaran harus didukung dengan jumlah benih yang cukup dan berkualitas.

Dilihat dari segi bisnis, suatu usaha akan berkembang baik apabila dapat mengasilkan keuntungan yang tinggi sehingga pendapatan pembudidaya meningkat. Daerah Bogor merupakan daerah yang cukup dinamis terhadap perkembangan budidaya perikanan air tawar.Penelitian ini bertujuan untuk memperoleh informasi kisaran luas lahan pendederan ikan bawal yang ideal bagi pembudidaya dan memperoleh gambaran kelayakan usaha terhadap modal yang dimanfaatkan.

Prosedur penelitian di mulai dari pengadaan saprodi. Tiap bacth/ ulangan pada kelompok penelitian penelitian dilakukan kegiatan meliputi ; pengolahan persiapan lahan, penebaran larva, pemeliharaan dan pemanenan. Penelitian menggunakan rancangan acak lengkap (RAL), dengan tiga perlakuan, pada luasan yang berbeda $\left(500 \mathrm{~m}^{2}, 100 \mathrm{~m}^{2}\right.$ dan $1500 \mathrm{~m}^{2}$.)

Data yang dikumpulkan dari hasil pengamatan adalah biaya tetap, biaya variabel, pendapatan total, dan informasi upah minimum regional Bogor. Metode analisis yang di lakukan adalah, laba/rugi, R/C ratio, BEP produk,BEP harga, dan pay back period.
\end{abstract}

Kata Kunci : Luasan Lahan, Analisa Finansial, Upah Minimum Regional (UMR)

\section{PENDAHULUAN}

\section{Latar Belakang}

Kabupaten Bogor merupakan daerah yang cukup dinamis terhadap perkembangan budidaya perikanan air tawar. Masyarakatnya cukup dinamis terhadap perkembangan budidaya perikanan air tawar. Masyarakat juga antusias menerima teknologi dan komoditas jenis baru yang mendapat respon sangat baik bagi masyarakat perikanan di daerah Bogor.

Budidaya pembesaran ikan bawal menunjukan kecenderungan meningkat di sebabkan peningkatan permintaan pada tingkat ukuran konsumsi. Hal tersebut berimplikasi pada peningkatan permintaan benih baik dari kuantitas maupun kualitas. Produksi benih bawal daerah Bogor tidak hanya untuk memenuhi kebutuhan lokal namun sebagian dikirim keluar pulau Jawa seperti Sumatera,Bali,Nusa Tenggara dan Kalimantan.

Untuk memproduksi benih bawal $3 / 4$ sampai 1 inci terdapat segmen kegiatan tersendiri yaitu usaha pendederan. Kegiatan tersebut dilakukan oleh para pembudidaya yang tidak memiliki hatchery.Kegiatan biasanya dilakukan pada unit - unit 
pembenihan rakyat (UPR) skala kelompok kecil atau keluarga, baik sebagai usaha pokok atau hanya sebagai usaha sampingan. Melihat kenyataan bahwa kegiatan pendederan ikan bawal menjadi salah satu jenis usaha atau kegiatan usaha tersendiri maka di perlukan kajian yang lebih terinci dan detail yang berkaitan dengan parameter parameter analisis ekonomi pada kegiatan usaha tersebut.

Salah satu tolok ukur pendapatan masyarakat yang layak untuk memenuhi kebutuhan standar minimal adalah tingkat upah minimum. Kegiatan pendederan ikan bawal sebagai salah satu kegiatan ekonomi perlu mendapatkan informasi kajian atau analisis yang berkaitan besaran skala usaha yang di sertakan dengan upah minimum regional (UMR). Kajian analisis ekonomi yang memiliki validitas yang baik akan membantu ketepatan dalam memprediksi input dan output dalam usaha pendederan ikan bawal.

\section{Rumusan Masalah}

Setiap kegiatan perekonomian tentu mengharapkan efisiensi dan efektifitas dalam penggunaan faktor-faktor produksi. Kegiatan pendederan ikan bawal merupakan salah satu kegiatan produksi yang menggunakan sumber tenaga manusia. Sumbe tenaga manusia merupakan faktor produksi yang tidak dapat disimpan atau ditunda menggunaannya seperti faktor produksi lain yang berupa bahan atau barang, karena biaya akan terus dikeluarkan seiring dengan berjalannya waktu. Untuk itu penggunaanya harus tepat agar tidak terjadi kelebihan tenaga kerja atau pengangguran tak kentara. Dengan metode analisis data yang diambil dari data deskriftif hasil uji/penelitian yang didasarkan pada variabel-variabel input dan output maka akan ditemukan titik besaran skala usaha dinyatakan dengan luasan lahan yang dapat memberikan penghasilan nilai nominal setara dengan upah minimum regional (UMR).

\section{Tujuan penelitian}

1. Memperoleh informasi kisaran luas lahan pendederan ikan bawal yang ideal bagi pembudidaya.

2. Memperoleh gambaran kelayakan usaha terhadap modal yang dimanfaatkan

\section{Kontribusi Penelitian}

1. Dapat menghasilkan data dan informasi untuk penelitian lanjutan

2. Sebagai bahan acuan bagi calon investor untuk menentukan besaran skala usaha dan jumlah tenaga kerja yang diperlukan

3. Menekan timbulnya kelebihan tenaga kerja atau pengangguran tak kentara pada kegiatan usaha pendederan ikan bawal.

\section{KERANGKA PIKIR, VARIABEL, PENELITIAN DAN HIPOTESIS}

\section{Kerangka Pemikiran}

Faktor-faktor produksi diproses dengan melakukan manajemen dan penanganan teknis serta berinteraksi dan dipengaruhi oleh faktor sosial ekonomi dimana kegiatan dilakukan, yang nantinya akan menghasilkan produk sesuai dengan besaran input yang diberikan. Hasil nominal dari produksi atau total output dipengaruhi oleh tingkat harga barang hasil produksi, sementara harga sangat dipengaruhi kualitas barang, posisi tawar dan harga pasar. Harga pasar dipengaruhi oleh tingkat equilibrium antara suplai dan permintaan serta jenis barang subtitusinya. 
Faktor penentu dari hasil akhir atau output bersih yang kemudian dinyatakan dalam bentuk nominal berupa pendapatan adalah besaran jumlah produksi dikalikan harga satuan dikurangi input total. Secara rasional dan dalam keadaan normal besaran jumlah produksi berkorelasi dengan besaran jumlah input yang diberikan. Dalam kegiatan usaha pendederan ikan bawal besaran jumlah input secara maksimal dibatasi oleh faktor teknis yaitu luasan lahan pemeliharaan.

\section{Varibel Penelitian}

a. Faktor internal perusahaan
1) Harga
2) Jumlah Produksi
3) Luasan Lahan

b. Faktor eksternal

1) Iklim dan Cuaca

2) Hama dan Penyakit

\section{Hipotesis}

Luasan lahan usaha berpengaruh terhadap besaran input yang dibutuhkan dan output yang dihasilkan.

\section{PELAKSANAAN KEGIATAN}

\section{Tempat dan Waktu Penelitian}

Penelitian dilakukan di lapangan praktik STP Jurluhkan Desa Pasir Jaya Kecamatan Bogor Barat Kabupaten Bogor, dimulai dari bulan Juli sampai dengan bulan November 2009.

\section{Bahan dan Alat Penelitian}

Bahan Penelitian dibutuhkan bahan berupa larva ikan bawal, pupuk kandang, pakan (pelet), dan obat-obatan. Sedangkan peralatan yang diperlukan adalah cangkul, lambit, timbangan, anco atau waring, saringan greeding, hapa, dan alat tulis.

\section{Prosedur Penelitian}

Tahapan prosedur penelitian di mulai dari pengadaan saprodi. Tiap bacth/ ulangan pada kelompok penelitian penelitian dilakukan kegiatan meliputi ; pengolahan persiapan lahan, penebaran larva, pemeliharaan dan pemanenan. Penelitian menggunakan rancangan acak lengkap (RAL), dengan tiga perlakuan, pada luasan yang berbeda $\left(500 \mathrm{~m}^{2}, 100 \mathrm{~m}^{2}\right.$ dan $1500 \mathrm{~m}^{2}$.)

\section{Pengumpulan Data}

Data yang dikumpulkan dari hasil pengamatan adalah:

1. Biaya tetap

2. Biaya Variabel

3. Pendapatan Total

4. Informasi Upah Minimum Regional Bogor

\author{
Metode Analisis Yang di Lakukan Adalah : \\ 1. Laba/ Rugi \\ 2. R/C Ratio \\ 3. BEP Produk \\ 4. BEP Harga \\ 5. Pay Back Period
}

\section{HASIL DAN PEMBAHASAN}

Penelitian yang telah dilaksanakan dilahan praktek milik jurusan Penyuluhan Perikanan Bogor di lakukan dengan metode Rancangan Acak Lengkap ( RAL ). Perhitungan dilakukan pada 2 putaran karena pada putaran ke 3 mengalami gagal panen akibat dari tanggul utama jebol, sehingga kolam menjadi kering dan gagal panen. Data analisa rataan dapat dilihat pada tabel 1 . 
Tabel 1. Analisa Rataan Hasil Analisa Usaha

\begin{tabular}{|l|l|l|c|}
\hline \multirow{2}{*}{\multicolumn{1}{|c|}{ Perhitungan }} & \multicolumn{3}{|c|}{ Luasan } \\
\cline { 2 - 4 } & \multicolumn{1}{|c|}{$500 \mathrm{~m}^{2}$} & \multicolumn{1}{c|}{$1000 \mathrm{~m}^{2}$} & $1500 \mathrm{~m}^{2}$ \\
\hline Input & Rp 1.747 .870 & Rp 2.547.870 & \\
Output & Rp 1.750 .000 & Rp 3.500.000 & \\
BEP Produk & 3495 ekor & 50597 ekor & \\
BEP Harga & Rp 49,90 & Rp 36,40 & \\
Pay Back Period & 820,5 bulan & 2,67 bulan & \\
\hline
\end{tabular}

Dari tabel 1 dapat di deskripsikan bahwa :

1. Keuntungan rata rata pada luasan 500 $\mathrm{m}^{2}$ adalah $\mathrm{Rp} 2.130$,- dan pada luasan $1000 \mathrm{~m}^{2}$ adalah $\mathrm{Rp}$ 952.130,-. Hal ini menunjukan bahwa luasan $1000 \mathrm{~m}^{2}$ keatas baru bisa mencapai nilai penghasilan setara dengan UMR wilayah Bogor yakni minimal $\mathrm{Rp}$ 873.500,-

2. R/C Ratio pada luasan $500 \mathrm{~m}^{2}$ adalah 1,004 dan pada luasan $1000 \mathrm{~m}^{2} \quad 1,37$ Hal ini dapat diartikan bahwa jika kita tanam modal $\mathrm{Rp} 1$, maka pada luasan $500 \mathrm{~m}^{2}$ menghasilkan untung 0,004 Dan pada luasan $1000 \mathrm{~m}^{2}$ memperoleh untung 0,37 .

3. Nilai break even point produk dan break even point harga pada luasan $500 \mathrm{~m}^{2}$ menunjukan angka 3495,4 dan Rp. 49,9. Angka ini nyaris sama dengan harga jual dan produk yang di hasilkan. Kondisi seperti ini menunjukan bahwa keuntungan sangat kecil sedangkan luasan 1000 $\mathrm{m}^{2}$, BEP produk rata-rata 50957 ekor dan BEP harga Rp. 36,4. Dari data ini dapat diartikan jika menghasilkan di atas 50.957 ekor dan harga Rp.50 maka akan untung.

4. Pay Back period pada luasan $500 \mathrm{~m}^{2}$ jauh lebih besar dai pada kegiatan usaha di luasan $1000 \mathrm{~m}^{2}$. Hal ini berarti pengembalian modal lebih cepat pada luasan $1000 \mathrm{~m}^{2}$ atau lebih.

\section{KESIMPULAN DAN SARAN}

\section{Kesimpulan}

a. Hasil penelitian yang di lakukan di kolam Pasir Jaya Bogor, pada luasan $500 \mathrm{~m}^{2}$ nilai keuntungan Rp. 2130 dan pada luasan $1000 \mathrm{~m}^{2}$ adalah $\mathrm{Rp}$. 952130. Dari hasil ini dapat di tarik kesimpulan bahwa untuk memperoleh keuntungan setara dengan UMR ( Rp. 873.230 ) harus dilakukan pada luasan minimal $1000 \mathrm{~m}^{2}$.

b. Ideal tenaga kerja yang dibutuhkan untuk bekerja di pendederan ikan bawal adalah 1 orang dalam luasan $1000 \mathrm{~m}^{2}$

\section{Saran}

Dari hasil penelitian ini dapat disarankan Hendaknya menggunakan luasan minimal $1000 \mathrm{~m}^{2}$ agar usaha pendederan bawal mendapatkan untung setara dengan Rp 873.231,00 (UMR) Bogor. 


\section{DAFTAR PUSTAKA}

http://www.wikipedia.com/

http://www.bbat.go.id/
Kotler,P. Manajemen Pemasaran.-Analisis Perencanaan dan Pengendalian. Erlangga Jakarta

Sartono,A. 1997. Manajemen Keuangan. Universitas Gajah Mada.

Yogyakarta 